\title{
NEWS AND NOTES
}

\author{
PERSONAL AND MISCELLANEOUS \\ Compiled by the Managing Editor
}

The forty-fourth annual meeting of the American Political Science Association will be held next December 28-30 in Chicago, with headquarters at the Palmer House. As appointed by President Henry R. Spencer, the committee on program consists of Professors James K. Pollock (University of Michigan), chairman, Eric C. Bellquist (University of California), Herman C. Beyle (Syracuse University), Hugh A. Bone, Jr. (Queens College), Hugh L. Elsbree (Library of Congress), James Hart (University of Virginia), Lloyd M. Short (University of Minnesota), and Benjamin F. Wright (Harvard University).

Dr. Kurt Schuschnigg, former chancellor of Austria, has been appointed professor of government at St. Louis University and will offer courses in international relations and recent political theory.

Stanford University has given Professor Robert H. Connery leave during the spring quarter to serve in the office of the Under Secretary of the Navy.

Dr. Cromwell A. Riches has resigned his position as chief of the United Kingdom Section, Office of International Trade, Department of Commerce, to accept appointment as executive secretary of the Board of Foreign Service Examiners, Department of State.

At the University of Maryland, under the auspices of the department of government and politics, Professor E. E. Schattschneider, of Wesleyan University, delivered in March three public lectures on "The Struggle for Party Government."

Under the auspices of the National Foundation for Education in American Citizenship, Professor Carl J. Friedrich, of Harvard University, delivered a lecture and conducted a seminar at the Illinois Institute of Technology on February 27 on "European Reconstruction and the Future of Democratic World Order."

Professor Harold J. Laski, of the London School of Economics and Political Science, served as visiting professor of political science at Roosevelt College, Chicago, during the month of April. In addition to seminars and other classroom responsibilities, he delivered a series of public lectures on "America, Europe, and World Peace."

Professor William Anderson, on sabbatical leave from the University of Minnesota during the winter quarter, visited a considerable number of 
universities in Southern and Western states, observing their departments of political science.

In mid-winter, Professor Philip C. Jessup, of Columbia University, was named deputy to Warren R. Austin, chief United States representative in the United Nations Little Assembly.

Dr. Angelo P. Sereni, of the University of Ferrara, and now lecturing on comparative law at the Law School of New York University, will deliver a series of lectures on international law at the Academy of International Law, The Hague, during the month of July.

Professor Marshall E. Dimock has resigned his position as professor of political science at Northwestern University, effective at the end of the present academic year. He and Mrs. Dimock plan to live on their farm at Bethel, Vermont, where they will continue their research and writing.

Professor William Ebenstein, of Princeton University, has been granted leave of absence for the calendar year 1948 to direct a study of the status of the political science profession in selected countries in Europe. The undertaking is a project of UNESCO. Professor Ebenstein will make his headquarters in Paris.

During the coming summer, Professor Dayton D. McKean, on leave from Dartmouth College during the present term, will teach at the University of Colorado; Professor John Masland, at Columbia University; and Dr. A. M. Wilson, at the State University of Iowa.

Professor R. W. Van Wagenen, of Duke University, will lecture at the Institute of World Affairs of the San Diego State College in the first week of August and teach in the summer session at that institution.

At the request of the Under Secretary of the Army, Vanderbilt University has granted Professor Henry N. Williams a two-term leave of absence to enable him to join the staff of Major General Daniel Noce in completing a history of the Civil Affairs Division to be published as part of the ninety-nine volume, U. S. Army in World War II.

Dr. Milton Conover, who taught at New York and Yale Universities several years ago and has since travelled and lived abroad extensively, has of late been teaching again at New York University and serving as legal adjudicator at the Veterans Administration offices in Newark, N. J.

Professors Llewellyn Pfankuchen, of the University of Wisconsin, and Carroll Hawkins, of Michigan State College, will teach at the University of Minnesota during the coming summer session. 
Professor Harold S. Quigley, of the University of Minnesota, was the guest of the department of history and political science at Michigan State College on February 11, speaking on the topic, "Democracy in Japan: Progress and Problems."

The National Institute of Arts and Letters recently awarded its Gold Medal "for distinguished achievement" to Dr. Charles A. Beard, and formal presentation will be made at the annual joint ceremonial of the National Institute of Arts and Letters and the American Academy of Arts and Letters in May. Under a scheme of rotation among fields of achievement, the award is made for history and biography once every ten years.

After serving as visiting professor at Stanford University during the autumn, Professor Robert $\mathrm{S}$. Rankin resumed his duties at Duke University at the opening of the second semester.

Mr. John R. Ross, general deputy to Warren R. Austin, chief American delegate to the United Nations, was the featured speaker at Stanford University on February 20 at the opening of a three-day student international relations conference.

At the University of Utah, a separate department of political science has lately been created, with Professor G. Homer Durham, director of the Institute of Government, as chairman.

At Queens College, Dr. John Meng has been promoted to an associate professorship.

Professor W. Leon Godshall, of Lehigh University, will teach at the University of Connecticut during the coming summer.

Professor Elmer Plischke, of DePauw University, was named recently to the publications committee of the Indiana Academy of Social Sciences.

Mr. Jack R. Howard has been appointed instructor at the University of Pennsylvania, replacing Mr. Charles H. Harry, who has been appointed assistant district attorney of Montgomery county, Pa.

Miss Esther M. Seeman, formerly an instructor at the University of Minnesota, has been appointed lecturer in political science at Roosevelt College, Chicago.

A new political science journal, the Western Political Quarterly, is published for the recently established Western Political Science Association by the Institute of Government at the University of Utah. The managing editor is Professor F. B. Schick, of the University of Utah, and nineteen other members of the editorial board are widely distributed among col- 
leges and universities of the Rocky Mountain and Pacific Coast states. The first issue of the Quarterly was scheduled to appear in April.

At Lehigh University, Professors Eugene H. Miller, of Ursinus College, and Walker Kirchner, of the University of Delaware, are serving as visiting professors of international relations. During the coming summer, Professor Aurie N. Dunlap, of Sampson College, will similarly serve as visiting professor.

Professor Charles C. Rohlfing, of the University of Pennsylvania, addressed the annual convention of the Pennsylvania State Association of Township Supervisors on February 12 on the "Ordinance-Making Power of Townships"; and Drs. Norman D. Palmer and Robert Strausz-Hupé have lately delivered a series of addresses in forums sponsored by the Foreign Policy Association.

Mr. J. Murray Edelman, after recently receiving his doctorate at the University of Illinois, has been appointed instructor in that institution and research assistant in its Institute of Labor and Industrial Relations.

Dr. Robert E. Ward has been appointed to an instructorship at the University of Michigan.

Dr. Charles Prince has been appointed adviser on international and Soviet Russian affairs to Standard Oil Company (New Jersey). Previously, Dr. Prince held a similar position with the Chamber of Commerce of the United States.

Dr. Eve Lewis, formerly of the University of Utah, has accepted appointment at the University of Alabama as assistant professor.

Dr. Leon Ellis, lecturer in political science at Duke University, took part in a round table at the Social Science Forum sponsored by the Woman's College, University of North Carolina, on February 14. The other members of a panel discussing the question, "Can Nationalism Survive the Atomic Age?," were Professors William F. Ogburn and Maynard Krueger, both of the University of Chicago.

Under the leadership of former President Herbert Hoover, as chairman, the Committee on Organization of the Executive Branch of the Government has been setting up groups of experts in a variety of areas, and among appointments announced are those of Professor John M. Gaus, of Harvard University, to the group on agricultural activities, and Professor William Anderson, of the University of Minnesota, to the group on federal-state relations.

A European seminar-tour, designed especially for teachers and students of international relations, is being organized by Dr. Alfred G. Fisk, of 
San Francisco State College, as a part of the institution's summer session. The group will interview political and cultural leaders and visit government ministries, party headquarters, and such international organizations as UNESCO and the UN in Geneva.

A sponsoring committee composed of thirty-nine persons prominent in business and public life, has been created to advise Princeton University in planning an enlargement of its School of Public and International Affairs as a living memorial to Woodrow Wilson, the University's thirteenth president.

At the National University of Mexico, during the first half of January, Dr. Josef L. Kunz, of the University of Toledo, gave a series of four lectures in Spanish on "The Pure Theory of Law" and conducted two round-tables on actual problems of international law. His lectures and round-table discussions will be published in the Law Review of the National Law School of Mexico. Dr. Kunz was also made an honorary member of the Mexican National Bar Association.

At Duke University, a Government Forum was sponsored by the Woman's Student Government Association February 4-6. Speakers included Congressman George Mahon of Texas, a member of the Herter Committee, who spoke on the position of the United States in the international affairs of Europe; Mr. J. Francis Paschal, research director of the North Carolina Commission for the Improvement of the Administration of Justice; Professor Paul Clyde, of the Duke University department of history; and Mr. A. Emil Davies, British financier, member of the London County Council and officer of the Fabian Society.

Dr. John W. Manning, professor of government and public administration at the American University, Washington, D. C., since his release from the Army as a colonel, has been made commissioner of finance for the state of Kentucky. In this capacity, he is responsible for the state budget, for personnel management, for state purchasing, and for state accounts. His headquarters are in the State Office Building, Frankfort, Ky.

Political scientists from Washington, Oregon, Idaho, and British Columbia planned to meet at Reed College, Portland, Oregon, April 17-18, for organization of a Pacific Northwest Political Science Association. In addition to a business session and several scheduled addresses, panel discussions were projected on (1) federal-state relations in the Northwest, (2) the Marshall Plan, (3) the 1948 elections: political strategy and public opinion, (4) current concepts of individual and group rights, and (5) the teaching of political science in the Northwest. Professor Thomas I. Cook, of the University of Washington, was to serve as president pro tempore. 
Princeton, Cornell, Harvard, and Syracuse Universities are coöperating in the preparation of case reports drawn from actual administrative experience in the federal government, to be used for teaching purposes in the public administration schools of the four universities. A special research staff will be guided by an advisory committee representing the coöperating institutions. The Carnegie Corporation has recently made a grant of $\$ 100,000$ to Syracuse University in support of the project. The Corporation has also made a grant of $\$ 65,000$ over three years to the University of Puerto Rico toward support of a public administration program providing training for Puerto Ricans who wish to enter governmental service in Puerto Rico. Specialists in public administration from the United States will participate, and in-service training is also being provided for officials of the Puerto Rican government.

During recent months, the Coro Foundation, a public trust established in San Francisco in 1941, has been recruiting a group of twelve veterans of World War II interested in public service as a career. The men selected will receive $\$ 900$ scholarships and become "interns" on October 1 for a nine-month course designed to give them a first-hand acquaintance not only with municipal affairs but with the workings of labor, industry and civic organizations. Working in pairs, the interns, during the first two months, will observe the operations of industry. This will be followed by two months with unions, and afterwards by two months with administrative offices of the city and county of San Francisco, including attendance at legislative and committee hearings. Three months will be spent polling public opinion and otherwise trying to ascertain the attitude of citizens toward local government. In addition to sponsoring its program of internship in municipal affairs, the Foundation is conducting a laboratory course in government in conjunction with Bay Area colleges. Seventy-five students of political science, journalism, and similar subjects meet with government officials and labor and industrial leaders in seminars one afternoon a week for ten weeks.

The American University, School of Social Sciences and Public Affairs, in coöperation with the Washington Chapter of the American Political Science Association, announces that its Second Annual Institute for Teachers of Government and Administration will be held in Washington, D. C., June 13-27. The committee appointed to plan and direct the program includes Hugh L. Elsbree, Ernest S. Griffith, Donald C. Stone, and Francis O. Wilcox, of the American Political Science Association, and Pitman B. Potter, Catheryn Seckler-Hudson, Ernst Posner, and Lowell H. Hattery, of the American University. Participants in the Institute will engage in discussions with leaders of the national government concerning vital current issues and developments. Conferences will be held with 
members of congressional committees, officials of executive departments and agencies, representatives of major lobby groups, and other persons in the nation's capital who can contribute information that will enable the professor of political science and administration to make his classroom presentation more realistic. Special attention will be given to sources of helpful documentary and fugitive materials which will enrich the teaching of government and administration. Inquiries for further information about the Institute should be addressed to Lowell $\mathrm{H}$. Hattery, director, Institute for Teachers of Government and Administration, American University, 1901 F Street, N.W., Washington, D. C. 